\title{
ВЗАЄМОЗВ'ЯЗОК ПОКАЗНИКІВ КОМПОНЕНТНОГО СКЛАДУ ТІЛА З ФУНКЦІОНАЛЬНИМ СТАНОМ СЕРЦЕВО-СУДИННОї СИСТЕМИ У ЖІНОК МОЛОДОГО ВІКУ ЗАЛЕЖНО ВІД ТИПУ ГЕМОДИНАМІКИ
}

\author{
○М. І. Немеш, О. П. Кентеш, О. С. Паламарчук, О. Є. Костенчак-Свистак, В. П. Фекета \\ ДВНЗ «Ужгородський національний університет»
}

РЕЗЮМЕ. На сьогоднішній день визначення компонентного складу тіла дозволяє нам оцінити фізичний стан людини. Таким чином опосередковано можна визначити функціональні можливості організму.

Мета - визначити можливий різний зв'язок між певними компонентами складу тіла та показниками гемодинаміки з врахуванням гендерних відмінностей між компонетним складом тіла.

Матеріал і методи. В статті представлено дослідження з визначення впливу компонентного складу тіла на функціональний стан серцево-судинної системи у жінок. У дослідженні взяла участь 41 студентка віком від 18 до 25 років. Вимірювання маси тіла, ІМТ та показників вмісту загального жиру (ВЗЖ) та вісцерального жиру (ВВж), вмісту безжирової маси (ВБМ) проводили з використанням аналізатора складу тіла Tanita BC-601. Функціональний стан серцево-судинної системи (ССС) оцінювали за допомогою грудної реографії з використанням реографічного комплексу «РЕОКОМ». Критерієм поділу жінок за показниками компонентного складу тіла та серцево-судинної діяльності був тип гемодинаміки: 24 жінки мали еукінетичний тип гемодинаміки (I група), 17 - гіпокінетичний тип (II група).

Результати. У результаті проведеної статистичної обробки даних було виявлено кореляційний зв'язок між хвилинним об'ємом крові (ХОК) та загальним периферійним опором (ЗПО) з ВВЖ у I групі. При аналізі кореляційних співвідношень у жінок з гіпокінетичним типом гемодинаміки (II група) було виявлено, що ХOK має помірний позитивний кореляційний зв'язок з ВЗЖ, та негативний зв'язок з ВБМ.

Висновки. Збільшений вміст жирової тканини в жіночому організмі, порівняно з чоловічим, більшою мірою впливає не тільки на метаболічні процеси, а й на функціональний стан серцево-судинної системи. Таким чином, формування фізичного навантаження в жінок базуватиметься на показниках компонентного складу тіла та функціональних можливостях ССС.

КЛЮчОВІ СЛОВА: компонентний склад тіла; типи гемодинаміки; функціональний стан серцево-судинної системи.

Вступ. Еволюційний розвиток дослідження компонентного складу тіла починався з уявлень про те, що жирова тканина - це «зло», з яким потрібно боротися і намагатися утримувати його на низькому рівні, щоб запобігти появі ожиріння, захворювань серцево-судинної системи [1]. Водночас м'язова тканина сприймалася як сприятливий компонент тіла. Відповідно до цих уявлень, всі, як жінки, так і чоловіки, наполегливо тренували мускулатуру і зменшували вміст жирової тканини. Це, у свою чергу, часто призводило до маскулінізації жінок та гіпертрофії серцевого м'яза, підвищення артеріального тиску в результаті інтенсивних тренувань [2].

Ці факти спонукали до перегляду уявлень щодо оптимального співвідношення м'язової та жирової тканин, що привело до появи нової парадигми про те, що жирова та м'язова тканини є повноцінним ендокринним органом. Наприклад, м'язова тканина продукує численні міокіни, одним з яких, зокрема, $\epsilon$ інтерлейкін - 6 (ІЛ-6). Було з'ясовано, що підвищення ІЛ-6 у відповідь та тренування стимулює секрецію глюкагон-подібного пептиду-1 $\beta$-клітинами підшлункової залози, що, в свою чергу, впливає на секрецію інсуліну відповідно до рівня глікемії [3].
Успіхи фундаментальних наук дозволили поновому оцінити функції жирової тканини. Велике значення має відкриття ряду гормоноподібних речовин, що секретуються адипоциами і впливають на регуляцію апетиту і процеси ліполізу [4].

Еволюційний розвиток дослідження компонентного складу тіла стосується також розподілу жирової тканини в тілі людини. Загальновідомим $є$ факт, що розподіл м'язової і жирової тканини та метаболічні процеси в цих тканинах у жінок та чоловіків кардинально відрізняються. Наприклад, у жінок жирова тканина найбільше акумулюється в підшкірних ділянках, а для чоловіків характерний абдомінальний тип накопичення жирової тканини. До того ж, у період відпочинку жіночий організм буде конвертувати вільні жирні кислоти в тригліцериди з метою накопичення, а в чоловічому організмі вільні жирні кислоти окислюються [5].

Мета - дослідити зв'язок між показниками серцевої діяльності та показниками компонентного складу тіла у жінок молодого віку.

Матеріал і методи дослідження. В дослідженні взяла участь 41 здорова студентка віком від 1825 років, в якої не діагностовано гострих та хронічних захворювань. Жінки були ознайомлені із змістом процедур вимірів і давали згоду на їх прове- 
Огляди літератури, оригінальні дослідження, погляд на проблему, ювілеї

дення. При проведенні комплексних біологічних обстежень за участі студентів дотримувалися Гельсінської декларації Всесвітньої медичної асоціації щодо етичних принципів медичних досліджень за участі людини в якості об'єкта досліджень [6].

Вимірювання маси тіла, а також визначення таких параметрів як індекс маси тіла (IMT, кг/M²), відсотковий вміст загального жиру (ВЗЖ, \%), вміст вісцерального жиру (ВВЖ, од.) та вміст безжирової маси (ВБМ, \%) проводили з використанням біоелектричного імпедансного аналізатора TANITABC-601 (Японія).

Показники гемодинаміки визначали за допомогою грудної реографії за методом Кубічека з використанням реографічного комплексу «РЕОKOM» (Національний аерокосмічний університет імені М. Є. Жуковського «Харківський авіаційний інститут» М. Харків). В якості показників серцевої діяльності були використані:

- частота серцевих скорочень (ЧСС, уд/хв) в нормі коливається в межах 60-90 уд/хв;

- хвилинний об'єм крові (ХОК, л/Хв) в нормі становить від 5-8 л/хв;

- ударний об'єм (УО, мл) - нормативні значення 60-100 мл/хв;

- робота лівого шлуночка (РЛШ, кг/м ) -4-7 кг/м;

- потужність лівого шлуночка (ПЛШ, ват) в нормі складає 2,0-5,40 ват;

- серцевий індекс $\left(\mathrm{Cl}\right.$, л/хв· $\left.{ }^{2}\right)$ - нормативні значення 2,2-3,7 л/хв· $^{2}$;

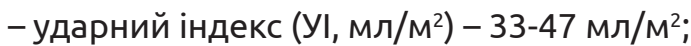

- загальний периферичний опір (3ПО,

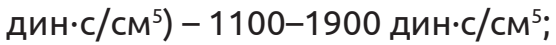

- питомий периферичний опір (ППО, дин.с. $\left.{ }^{2} / \mathrm{CM}^{5}\right)-1970-2390$ дин $\cdot \mathrm{C} \cdot \mathrm{M}^{2} / \mathrm{CM}^{5}$;

- індекс роботи лівого шлуночка (ІРлШ,

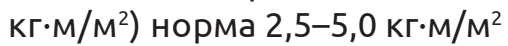

Відповідно до загальноприйнятої методики у обстежених визначали тип центральної гемодинаміки: еукінетичний, гіперкінетичний чи гіпокінетичний.

Результати були статистично опрацьовані за допомогою статистичної програми Minitab 17 з використанням кореляційного аналізу та Т-тесту Стьюдента для двох незалежних вибірок [7].

Результати й обговорення. Критерієм розподілу жінок за показниками компонентного складу та серцево-судинної діяльності був тип гемодинаміки. За даними огляду літератури, критеріями розподілу людей на типи гемодинаміки $є$ серцевий індекс (CI) та загальний периферичний опір (ЗПО) [8]. У результаті такого поділу виявилося, що 24 жінки мали еукінетичний тип гемодинаміки (58,5 \%), 17 - гіпокінетичний тип гемодинаміки (41,5\%).

Наступною частиною нашого дослідження було встановлення відмінностей між показниками компонентного складу тіла у жінок з еукінетичним та гіпокінетичним типами гемодинаміки 3 використанням Т-тесту Стьюдента для двох незалежних вибірок (табл. 1).

Таблиця 1. Відмінності показників компонентного складу тіла в I та II групах

\begin{tabular}{|c|c|c|}
\hline $\begin{array}{c}\text { Показники компонентного складу } \\
\text { тіла M, StDev }\end{array}$ & $\begin{array}{c}\text { І група } \\
\text { Еукінетичний тип } \\
(n=24)\end{array}$ & $\begin{array}{c}\text { II група } \\
\text { Гіпокінетичний тип } \\
(\mathrm{n}=17) \\
\end{array}$ \\
\hline $\mathrm{IMT}, \mathrm{k} / \mathrm{M}^{2}$ & $23,58 \pm 4,68$ & $21,77 \pm 3,21$ \\
\hline B3Ж, \% & $27,06 \pm 7,2$ & $26,19 \pm 7,09$ \\
\hline ВВЖ, од. & $2,70 \pm 2,42$ & $1,76 \pm 0,97$ \\
\hline ВБМ, \% & $68,55 \pm 7,73$ & $70,31 \pm 6,77$ \\
\hline
\end{tabular}

У результаті проведеного статистичного аналізу з'ясувалося, що статистично достовірної відмінності за показниками компонентного складу тіла не існує (p>0,05). Не дивлячись на те, що середні значення показників у двох обстежуваних групах знаходилися в межах норми, обстежувані мали різний тип гемодинаміки.

Наступним етапом дослідження було виявити відмінності між показниками гемодинаміки у вищевказаних групах жінок (табл. 2).

Таблиця 2. Відмінності між показниками гемодинаміки у I та II групах

\begin{tabular}{|c|c|c|}
\hline $\begin{array}{c}\text { Показники гемодинаміки M, } \\
\text { StDev }\end{array}$ & $\begin{array}{c}\text { І група } \\
\text { Еукіетичний тип } \\
(\mathrm{n}=24)\end{array}$ & $\begin{array}{c}\text { II група } \\
\text { Гіпокінетичний тип } \\
(\mathrm{n}=17)\end{array}$ \\
\hline 1 & 2 & 3 \\
\hline СAT, мM Рт.Ст & $91,56 \pm 8,99$ & $92,34 \pm 6,11$ \\
\hline ЧСС, уд/хв & $75,33 \pm 8,29$ & $72,06 \pm 8,96$ \\
\hline УО, мл & $55,25 \pm 15,32$ & $39,92 \pm 7,75^{* * *}$ \\
\hline УІ, мл/M² & $35,79 \pm 7,87$ & $26,66 \pm 4,96 * * *$ \\
\hline ХOK, л/Хв & $4,06 \pm 0,71$ & $2,79 \pm 0,46$ \\
\hline
\end{tabular}




\begin{tabular}{|c|c|c|}
\hline 1 & 2 & 3 \\
\hline $\mathrm{Cl}, \pi / \mathrm{XB} \cdot \mathrm{M}^{2}$ & $2,64 \pm 0,32$ & $1,89 \pm 0,27$ \\
\hline ЗПО, дин $\cdot с / \mathrm{cm}^{5}$ & $1678 \pm 251,85$ & $2437 \pm 458,9$ ** \\
\hline ППО, дин $\cdot \mathrm{c}^{2} / \mathrm{cm}^{5}$ & $2566 \pm 415,4$ & $3640 \pm 646,7^{* * *}$ \\
\hline РЛШ, кг/M & $4,79 \pm 1,05$ & $3,39 \pm 0,74 * *$ \\
\hline IРЛШ, $\mathrm{K} \cdot \mathrm{M} / \mathrm{M}^{2}$ & $3,098 \pm 0,479$ & $2,255 \pm 0,395^{* * *}$ \\
\hline Плш, ват & $2,56 \pm 0,985$ & $1,86 \pm 0,402^{* *}$ \\
\hline
\end{tabular}

Примітка. *p<0,05; **p<0,01; *** $<<0,001$ при зіставленні з І групою.

За результатами статистичної обробки даних було виявлено статистично значиму відмінність між групами за показниками $\mathrm{Cl}(\mathrm{p}<0,002), 3 П \mathrm{O}(\mathrm{p}<0,001)$ та ІРЛШ (p<0,001), ПЛШ (p<0,009). До того ж, при порівнянні двох груп статистично значимо відрізнялися такі показники гемодинаміки як УО $(p<0,001)$, УІ $(p<0,001)$, ХOК $(p<0,002)$ та ППО $(p<0,002)$.

Наступним етапом дослідження було з'ясувати, чи існує кореляційний зв'язок між показниками компонентного складу тіла та гемодинаміки в кожній окремій групі. В результаті проведеного кореляційного аналізу було встановлено, що ХOK та ЗПО корелював з ВВЖ $(r=0,4895 ; \quad p<0,015$; $r=-0,4530 ; p<0,026)$ у першій групі. Статистично вірогідний кореляційний зв'язок в цій групі був знайдений також між IMT та РЛШ $(r=0,5127 ; p<0,010)$.
Також після проведеного кореляційного аналізу було виявлено, що в еукінетичній групі ВЗЖ мав позитивний кореляційний зв'язок з ППО $(r=0,6082$; $\mathrm{p}<0,001)$ та негативний зв'язок з $\mathrm{Cl}(r=-0,4717$; $\mathrm{p}<0,04)$. ВБМ також мав статистично достовірний кореляційний зв'язок з Сl $(r=0,5127 ; p<0,03)$ та ППО ( $r=-0,6496 ; p<0.001)$. ППО та $\mathrm{Cl} \in$ інтегральними показниками ЗПО та ХОКу, які нівелюють вплив зовнішніх факторів під час їх визначення та дають більш об'єктивну інформацію щодо функціонального стану серця та судин. Отримані дані свідчать про те, що в групі обстежених з еукінетичним типом гемодинаміки існує збалансоване співвідношення жирової і м'язової тканин, що підтримує оптимальне функціонування серця та судинного русла (табл. 3).

Таблиця 3. Кореляційний зв'язок між показниками гемодинаміки і компонентного складу тіла в I групі

\begin{tabular}{|c|c|c|c|c|}
\hline Показники гемодинаміки & $\mathrm{IMT}, \mathrm{Kr} / \mathrm{M}^{2}$ & В3Ж, \% & ВВЖ, од & ВБМ, \% \\
\hline ЧСС, уд/хв & $-0,1012$ & $-0,1155$ & $-0,0852$ & 0,0966 \\
\hline САT, мм.рт.Ст & 0,1908 & 0,3950 & 0,0236 & $-0,4148 *$ \\
\hline УО, мл & 0,3958 & 0,1849 & 0,3820 & $-0,1127$ \\
\hline $\mathrm{Yl}, \mathrm{Mл} / \mathrm{M}^{2}$ & $-0,0353$ & $-0,1963$ & 0,0722 & 0,2346 \\
\hline ХОК, л/ХВ & $0,5474 * *$ & 0,2409 & $0,4895 * *$ & $-0,1481$ \\
\hline $\mathrm{Cl}, л / \mathrm{Xв} \cdot \mathrm{M}^{2}$ & $0-, 2447$ & $-0,4717^{*}$ & $-0,0920$ & $0,5127^{*}$ \\
\hline ЗПО, дин $\cdot \mathrm{c} / \mathrm{cm}^{5}$ & $-0,4107^{*}$ & 0,0129 & $-0,4530 *$ & $-0,1233$ \\
\hline ППО, дин $\cdot \mathrm{c}^{2} / \mathrm{cm}^{5}$ & 0,3328 & $0,6082 * *$ & 0,1134 & $-0,6496^{* *}$ \\
\hline РЛШ, кг/M & $0,5127^{*}$ & 0,3755 & 0,3867 & $-0,3107$ \\
\hline IPЛШ, $\mathrm{K} \Gamma \cdot \mathrm{M} / \mathrm{M}^{2}$ & $-0,0832$ & $-0,1171$ & $-0,0705$ & 0,1393 \\
\hline Плш, ват & 0,3173 & 0,1187 & 0,3457 & $-0,0751$ \\
\hline
\end{tabular}

Примітка. * $p<0,05 ; * * p<0,01 ; * * * 0<0,001$.

При аналізі кореляційних співвідношень у жінок з гіпокінетичним типом гемодинаміки (II група) було виявлено, що ХОК має помірний позитивний кореляційний зв'язок з ВЗЖ $(r=0,5544 ;$ $\mathrm{p}<0,021)$ та негативний зв'язок з ВБМ ( $r=-0,5293$, p<0,029). Встановлено, що ВЗЖ має обернено про- порційний кореляційний зв'язок з ЗПО ( $r=-0,4923$, $\mathrm{p}<0,045)$ та позитивний зв'язок з РЛШ $(r=0,5797$, p<0,015). За результатами статистичної обробки даних також було виявлено, що IMT мав сильний кореляційний зв'язок з ПЛШ $(r=0,6098 ; p<0,009)$ (табл. 4).

Таблиця 4. Кореляційний зв'язок між показниками гемодинаміки і компонентного складу тіла в II групі

\begin{tabular}{|l|c|c|c|c|}
\hline Показники гемодинаміки, & $\mathrm{IMT}, \mathrm{\kappa г} / \mathrm{M}^{2}$ & ВЗЖ, $\%$ & ВВЖ, од. & ВБМ, \% \\
\hline 1 & 2 & 3 & 4 & 5 \\
\hline ЧСС, уд/хВ & 0,1319 & 0,3241 & 0,880 & $-0,3589$ \\
\hline САТ, мм рт. ст. & 0,4380 & 0,4459 & 0,2976 & $-0,4111$ \\
\hline
\end{tabular}




\begin{tabular}{|c|c|c|c|c|}
\hline 1 & 2 & 3 & 4 & 5 \\
\hline ХOК, л/Хв & 0,3900 & $0,5544^{*}$ & 0,2270 & $-0,5293^{*}$ \\
\hline $\mathrm{Cl}, \pi / \mathrm{XB} \cdot \mathrm{M}^{2}$ & 0,0205 & 0,0521 & $-0,3403$ & $-0,0596$ \\
\hline ЗПО, дин $\cdot \mathrm{c} / \mathrm{cm}^{5}$ & $-0,4419$ & $-0,4923 *$ &,- 1513 & $0,4978 *$ \\
\hline ППО, дин $\cdot \mathrm{c}^{2} / \mathrm{cm}^{5}$ & 0,1437 & 0,1158 & 0,4433 & $-0,0924$ \\
\hline РЛШ, кг/M & $0,5880 *$ & $0,5797^{*}$ & 0,2863 & $-0,5495^{*}$ \\
\hline IPЛШ, $\mathrm{K} \Gamma \cdot \mathrm{M} / \mathrm{M}^{2}$ & 0,1902 & 0,2255 & $-0,1680$ & $-0,2173$ \\
\hline Плш, ват & $0,6098 * *$ & 0,4662 & 0,4539 & $-0,4121$ \\
\hline
\end{tabular}

Примітка. * $\mathrm{p}<0,05 ;{ }^{* *} \mathrm{p}<0,01 ; * * * 0<0,001$.

Враховуючи те, шо для гіпокінетичної групи

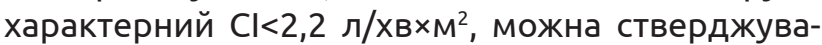
ти, що сила та кількість крові, що потрапляє у велике коло кровообігу у цієї категорії обстежених, буде зменшена. Таким чином, адаптаційно-компенсаторним механізмом $є$ вазоконстрикція, що, в свою чергу, може призвести до підвищення 3ПО, а згодом і артеріального тиску (АТ). Отримані дані свідчать про те, що жінкам з гіпокінетичним типом гемодинаміки варто контролювати рівень жирової тканини та намагатися підтримувати скелетну мускулатуру в тонусі, щоб запобігти виникненню гіпертрофії міокарда та артеріальної гіпертензії. За даними літератури, на відміну від вісцерального жиру, підшкірна жирова тканина продукує більше гормоноподібних речовин. Одна із них, - лептин, $-\epsilon$ антистеатогенним гормоном i регулює гомеостаз жирних кислот. Із збільшенням вмісту підшкірної жирової тканини, у зв'язку з висококалорійним харчуванням та гіподинамією, починає вироблятися фактор некрозу пухлин (ФНП-а), який може призвести до інсулінорезистентності $[4,9]$. Можна припустити, що наявність кореляційного зв'язку між ВЗЖ та РлШ у гіпокінетичній групі, порівняно з еукінетичною групою, детермінується розподілом жирової тканини в організмі жінки. Наприклад, жирова тканина, що знаходиться в черевній порожнині та в підшкірній клітковинні черевної порожнини, має сильний позитивний кореляційний зв'язок з появою інсулінорезистентності. Водночас, жирова тканина, що відкладається в ділянці стегон, має кардіопротективну здатність [10]. На підставі наших досліджень можна висунути гіпотезу про те, що в жінок з гіпокінетичним типом гемодинаміки жирова тканина більш виражена на тулубі, а збільшення їі відсоткового вмісту пов'язане з гіподинамією та висококалорійним харчуванням.

Висновки. Гендерна особливість розподілу м'язової та жирової тканин в організмі людини впливає на метаболічні процеси та стан здоров'я організму в цілому. На функціональний стан жіночого організму більшою мірою впливає жирова тканина та її розподіл в тілі. Вміст загального жиру та вісцерального жиру в жіночому організмі має статистично достовірний зв'язок з показниками гемодинаміки, що дає підставу для розробки програм індивідуальних фізичних навантажень в залежності від типу гемодинаміки з метою профілактики ожиріння.

Перспективи подальших досліджень. В майбутньомуплануємо продовжувати дослідження зв'язку між показниками компонентного складу тіла та функціональним станом серцево-судинної системи серед чоловіків молодого віку. А також зосередимо увагу на дослідженні впливу В3Ж в жінок на їх фізичні можливості та метаболічні процеси в їхньому організмі.

\section{ЛІТЕРАТУРА}

1. Obesity: preventing and managing the global epidemic (2000). (No. 894). World Health Organization. [Electronic resource].

2. Кудря О. Н. Адаптация сердечно-сосудистой системы спортсменов к нагрузкам разной направленности / О. Н. Кудря, Л. Е. Белова, Л. В. Капилевич // Вестник Томского государственного университета. - 2012. № 356.- C.162-166

3. Karstoft K. Skeletal muscle as a gene regulatory endocrine organ / K. Karstoft, B. K. Pedersen // Current Opinion in Clinical Nutrition and Metabolic Care. - 2016. No. 19 (4). - P. 270-275.

4. Ковалева Ю. В. Гормоны жировой ткани и их роль в формировании гормонального статуса и патогенезе метаболических нарушений у женщин / Ю. В. Ковале-

ва // Артериальная гипертензия. - 2015. - № 21 (4). C. $356-369$

5. Mauvais-Jarvis F. Sex differences in metabolic homeostasis, diabetes, and obesity / F. Mauvais-Jarvis // Biology of Sex Differences. - 2015. - No. 6 (1). - P. 14-21.

6. Vsesvitnia medychna asotsiatsiia (1964), Helsinska deklaratsiia Vsesvitnoi medychnoi asotsiotsai "Etychni pryntsypy medychnykh doslidzhen za uchastiu liudyny u yakosti obiekta doslidzhennia", vid 01.06.1964 г. - Retrieved from: http://zakon2.rada.gov.ua/laws/show/990_005।

7. Гланц С. Медико-биологическая статистика / С. Гланц. - М. : Практика, 1999. - Р. 82-117.

8. Гончарук М. Д. К методике определения типов центральной гемодинамики / М. Д. Гончарук // Наукові праці [Чорноморського державного університету імені 
Огляди літератури, оригінальні дослідження, погляд на проблему, ювілеї

Петра Могили комплексу Києво-Могилянська академія]. Серія: Техногенна безпека. - 2014. - № 238, Вип. 226. - С. 40-44.

9. Ronti T. The endocrine function of adipose tissue: an update / T. Ronti, G. Lupattelli, E. Mannarino// Clinical Endocrinology. - 2006. - No. 64 (4). - P. 355-365.

10. Body Fat: our own Janus / E. L. Thomas, J. D. Bell // Physiology News. - 2014. - No. 96. - P. 24-27.

\section{REFERENCES}

1. World Health Organization. (2000). Obesity: preventing and managing the global epidemic (No. 894). World Health Organization. [Electronic resource]

2. Kudrya, O.N., Belova, L.E., \& Kapylevich, L.V. (2012). Adaptatsiya serdechno-sosudistoy sistemy sportsmenov $\mathrm{k}$ nagruzkam raznoy napravlennosti [Adaptation of the cardiovascular system of athletes to exercises of different directions]. Vestnik Tomskogo gosudarstvennogo universiteta - Journal of Tomsk State University, (356) [in Russian].

3. Karstoft, K., \& Pedersen, B.K. (2016). Skeletal muscle as a gene regulatory endocrine organ. Current Opinion in Clinical Nutrition and Metabolic Care, 19 (4), 270-275

4. Kovaleva, Yu.V. (2015). Gormon zhyrovoy tkani i ikh rol v formirovanii gormonalnogo statusa v patogeneze metabolicheskikh narusheniy u zhenshchin [Adipose tissue hormones and their role in the formation of hormonal status and the pathogenesis of metabolic disorders in women]. Arterialnaya gipertenziya - Arterial Hypertension, 21 (4) [in Russian].

5. Mauvais-Jarvis, F. (2015). Sex differences in metabolic homeostasis, diabetes, and obesity. Biology of Sex Differences, 6 (1), 4-21.

6. (1964). Vsesvitnia medychna asotsiatsiia. Helsinska deklaratsiia Vsesvitnoi medychnoi asotsiotsai "Etychni pryntsypy medychnykh doslidzhen za uchastiu liudyny u yakosti obiekta doslidzhennia", vid 01.06.1964 r. [World Medical Association. Helsinki Declaration of World Medical Association "Etical Principles of Medical Studies with Participation of a Man as an Object of Research" of 06.01.1964]. Retrieved from: http://zakon2.rada.gov.ua/ laws/show/990_005\[in Ukrainian].

7. Glancz, $\bar{S}$. (1999). Mediko-biologicheskaya statistika [Medical and biological statistics]. Moscow: Praktika [in Russian].

8. Goncharuk, M.D. (2014). K metodike opredeleniya tipov tsentralnoy gemodinamiky [To the method of determining the types of central hemodynamics]. Naukovi pratsi Chornomorskoho derzhavnoho universytetu imeni Petra Mohyly kompleksu Kyievo-Mohylianska akademiia. Seriia: Tekhnohenna bezpeka - Scientific works of the Black Sea State University named after Peter Mohyla of the Kyiv-Mohyla Academy Complex. Series: Technological Safety, 238 (226), 40-44 [in Russian]

9. Ronti, T., Lupattelli, G., \& Mannarino, E. (2006). The endocrine function of adipose tissue: an update. Clinical Endocrinology, 64 (4), 355-365.

10. Thomas, E.L., \& Bell, J.D. (2014). Body Fat: our own Janus. Physiology News, 96, 24-27.

\section{ВЗАИМОСВЯЗЬ ПОКАЗАТЕЛЕЙ КОМПОНЕНТНОГО СОСТАВА ТЕЛА И ФУНКЦИОНАЛЬНОГО СОСТОЯНИЯ СЕРДЕЧНО-СОСУДИСТОЙ СИСТЕМЫ У ЖЕНЩИН МОЛОДОГО ВОЗРАСТА В ЗАВИСИМОСТИ ОТ ТИПА ГЕМОДИНАМИКИ} ОМ. И. Немеш, О. П. Кентеш, О. С. Паламарчук, О. Э. Костенчак-Свистак, В. П. Фекета ГвУз «Ужгородский национальный университет»

РЕЗЮМЕ. На сегодняшний день определение компонентного состава тела позволяет нам оценить физическое состояние человека. Таким образом опосредованно можна определить функциональные возможности организма.

Цель - определить возможную разную связь между определенными компонентами состава тела и показателями гемодинамики с учетом гендерных различий между компонетным составом тела.

Материал и методы. В статье представлено исследование с определением влияния компонентного состава тела на функциональное состояние сердечно-сосудистой системы женщин. В исследовании приняла участие 41 здоровая студентка в возрасте 18-25 лет. Измерение массы тела, ИМТ, показателей содержания общего жира (СОЖ), висцерального жира (СВЖ), содержания безжировой массы (СБМ) проводилось с использованием анализатора состава тела Tanita BC-601. Функциональное состояние сердечно-сосудистой системы оценивали при помощи грудной реографии с использованием реографического комплекса «РЕОКОМ». Критерием распределения женщин за показателями компонентного состава и сердечно-сосудистой деятельности был тип гемодинамики: 24 девушки имели эукинетический тип гемодинамики (первая группа), 17 - гипокинетический тип (вторая группа).

Результаты. В результате проведенной статистической обработки данных между двумя группами была обнаружена корреляционная связь между минутным объемом крови (МОК) и общим периферическим сопротивлением (ОПС) с СВЖ в первой группе. При анализе корреляционных соотношений у женщин с гипокинетическим типом гемодинамики (вторая группа) было выявлено, что МОК имеет умеренную положительную корелляционную связь с СОЖ и отрицательную связь с СБМ.

Выводы. Увеличенное содержание жировой ткани в женском организме, в сравнении с мужским, в значительной степени влияет не только на метаболические процессы, но и на функциональное состояние сердечно-со- 
Огляди літератури, оригінальні дослідження, погляд на проблему, ювілеї

судистой системы. Следовательно, формирование физической нагрузки у женщин будет зависеть от компонентного состава тела и функциональных возможностей сердечно-сосудистой системы.

КЛюЧЕВЫЕ СЛОВА: компонентный состав тела; типы гемодинамики; функциональное состояние сердечнососудистой системы.

\title{
INTERACTION OF INDICATORS OF THE COMPONENT COMPOSITION OF THE BODY WITH THE FUNCTIONAL STATUS OF THE CARDIOVASCULAR SYSTEM IN YOUNG AGE WOMEN DEPENDING ON THE TYPE OF HEMODYNAMICS
}

\author{
@M. I. Nemesh, O. P. Kentesh, O. S. Palamarchuk, O. Y. Kostenchak-Svystak, V. P. Veketa \\ Uzhhorod National University
}

SUMMARY. Nowadays, the measurement of body composition gives us ability to assess the physical condition of the human's body. Thuswise, we could suppose about the functional abilities of the body.

The aim - according to the gender difference in body composition, we presume that it should be different connection between indices of body composition and cardio-vascular system.

Material and Methods. The subject of this study were 41 young women aged from 18 to 25 . The weight, BMI and the indices of body composition were measured by body-analizator Tanita BC-601. The function of cardiovascular system was measured using medical device 'REOKOM'. The women were divided into groups according to the criteria of type of the hemodynamic. As a result, 24 women had eykinetic type of the hemodynamic (I group) and 17 women had hypokinetic type of the hemodynamic (II group).

Results. Firstly, the results show that there was the significant correlation between indices of visceral fat and cardiac output (CO). Secondly, the indices of fat mass (FM) and fat-free mass (FFM) had the significant correlation with the $\mathrm{CO}$ in the second group.

Conclusions. The findings of this study suggest that in comparison with the man's body, the increased amount of the fat mass in the woman's body has a greater influence on its metabolic processes. Moreover, it influences on the functional condition of the cardiovascular system. That is why, the woman's physical activity should be based on the body composition and functional condition of the cardio-vascular system.

KEY WORDS: body composition; types of hemodynamic; functional condition of the cardiovascular system.

Отримано 25.10.2018 